\title{
Effects of Fertilization on Physiological and Biochemical Parameters of Wumeng Sheep in China's Wumeng Prairie
}

\author{
Yongkuan Chi ${ }^{1,2}$, Zhenzhen Zhang², Chunjie Song ${ }^{1}$, \\ Kangning Xiong ${ }^{2}$, Xiaoyun Shen ${ }^{1-3 *}$
}

${ }^{1}$ School of Life Science and Engineering, Southwest University of Science and Technology, Mianyang, China ${ }^{2}$ State Engineering Technology Institute for Karst Desertification Control, Guizhou Normal University, Guiyang, China ${ }^{3}$ World Bank Poverty Alleviation Project Office in Guizhou, Southwest China, Guiyang, China

Received: 15 August 2018

Accepted: 3 December 2018

\begin{abstract}
To explore the effects of fertilization on physiological and biochemical parameters in the blood of the Wumeng semi-fine wool sheep and select the optimum fertilizer type, we carried out fertilization and grazing experiments on the perennial artificial grassland in Wumeng Prairie. The content of mineral elements in soil, forage and animal tissues was analyzed by atomic emission spectrometry. The blood parameters were analyzed by automatic blood cell analyzer and the blood biochemical parameters were detected by automatic biochemical analyzer. The results showed that fertilization significantly increased nitrogen content $(\mathrm{P}<0.01)$, but there was no significant difference between different fertilization treatments. Ammonium sulfate substantially increased the sulfur content of forage $(\mathrm{P}<0.01)$ and dramatically decreased the selenium content of forage $(\mathrm{P}<0.01)$. At the end of the grazing experiment, the content of copper, iron and selenium in the blood of the Wumeng sheep in the grassland enriched with ammonium sulfate was significantly lower than that in the grassland enriched with ammonium nitrate and the control group $(\mathrm{P}<0.01)$, and the sulfur content in the blood of the animals was obviously higher than that in the prairie enriched with ammonium nitrate and the control group $(\mathrm{P}<0.01)$. Ammonium sulfate fertilization evidently reduced the hemoglobin and erythrocyte hematocrit capacity of the sheep $(\mathrm{P}<0.01)$, while serum ceruloplasmin content, serum superoxide dismutase activity, serum glutathione peroxidase activity and serum catalase activity were significantly lower than that in the prairie enriched with ammonium nitrate and the control group $(\mathrm{P}<0.01)$. There were no significant differences in other trace elements, blood parameters and serum biochemical parameters between the fertilization treatment and the control group. Consequently, it is concluded that ammonium sulfate fertilization inhibit the metabolism of trace elements and decline some of the blood physiological
\end{abstract}

*e-mail: sfdxsxy@163.com 
and biochemical parameters in the sheep, which has a negative effect on their health, so we have suggested that the use of ammonium sulfate fertilizer should be reduced in pastures with low selenium, iron and copper contents.

Keywords: fertilizer treatment, ammonium sulfate, perennial artificial grassland, Wumeng semi-fine sheep, trace element, metabolism

\section{Introduction}

The Wumeng Mountains are the most important ecological barrier in the middle and upper reaches of the Yangtze and Pearl rivers. It is the essence of grassland and animal husbandry in southern China. Wumeng Prairie, one of the most important prairies in the Wumeng Mountains, is the highest alpine pastoral area with the largest area in southwestern China [1]. The contradiction between land resources and a large population in the region has become increasingly prominent, and the ecological footprint far exceeds the ecological carrying capacity $[1,2]$. With abundant water and heat resources, the prairie is a favorable environment for the growth of phytoma. The forage resources are very rich, and the development of mountain ecological animal husbandry has unique natural conditions [1-3]. The development of grassland and ecological animal husbandry in the prairie is strategic for improving the productivity of agriculture and animal husbandry, increasing the income of the poor, and controlling the ecological environment [2, 3].

In recent years, the rapid growth of livestock population and the irrational use of grassland resources has resulted in grassland degradation and desertification, the reduced grass yield, and the severely damaged grassland ecosystem function [3]. The Wumeng sheep are mainly distributed in the Wumeng Mountains at the junction of Guizhou, Yunnan and Sichuan provinces. The prairie is its core production area, with an amount of 1.15 million Wumeng sheep on hand $[1,3]$. The sheep, whose meat and wool are both used, was a kind of breed crossbred by native sheep and Corriedale. After upgrading from 1974 to 1981, cross-breeding from 1982 to 1984 , expansion and promotion from 1984 to 1990 , the Wumeng sheep formed a sheep breeding population with better production performance and relatively stable genetic performance $[4,5]$. The weight of adult rams and ewes is $51.62 \pm 5.37 \mathrm{~kg}$ and $41.32 \pm 5.73 \mathrm{~kg}$, respectively. The average wool yield of adult rams and ewes is $5.66 \mathrm{~kg}$ and $4.22 \mathrm{~kg}$, respectively. The wool length of adult sheep is $9.33-13.94 \mathrm{~cm}$ and the net wool rate is $56.72 \%$. The slaughter rates of the one-yearold wether and adult wether are $47.37 \%$ and $52.12 \%$, respectively. The lambing rate is $106.79 \%$ [2]. The sheep have high production performance, strong adaptability to alpine pastoral area and gentle temperament. As an excellent variety cultivated for many years, they are easy to manage and play a key role in the development of animal husbandry in the prairie. Trace elements are the most important nutrient for animals and plants, and are closely related to the physiological and biochemical parameters of the organism. Grassland fertilization will directly or indirectly affect the trace element content in forage, simultaneously affect the physiological and biochemical parameters of grazing animals through the food chain, and further influence the growth and health of the organism. If the essential trace elements are insufficient in plants and animals, their growth and development will be seriously affected, with subsequent various diseases and even death [4]. Consequently, the research of trace elements in the soil-grass-livestock system cannot only understand the circulation rule of trace elements in the soil-forage system and the nutritional status of grazing animals, but also have important theoretical and practical value for the management of artificial grassland livestock systems.

The purpose of this study is to explore the effects of prairie fertilization on the mineral metabolism and physiological and biochemical parameters of the Wumeng semi-fine wool sheep, find the most suitable fertilization method and fertilizer species for the perennial artificial grassland in Wumeng Prairie, and provide a basis for the efficient management of the soilgrass-livestock system in the prairie.

\section{Materials and Methods}

\section{Study Area}

The experimental grassland is located in Wumeng Prairie. The grassland type belongs to the perennial artificial grassland. The prairie is located at $102^{\circ} 37^{\prime} \mathrm{E}-106^{\circ} 35^{\prime} \mathrm{E}, 25^{\circ} 36^{\prime} \mathrm{N}-28^{\circ} 36^{\prime} \mathrm{N}$. The climate is characterized by cold winters and cool summers. The annual average annual temperature is $11.1^{\circ} \mathrm{C}$ and the annual average rainfall is more than $950 \mathrm{~mm}$. The altitude is more than $1600 \mathrm{~m}$ with the highest altitude $2867 \mathrm{~m}$. The main plant species are: Lolium perenne L., Trifolium repens L., Carex rigescens (Franch)V. Krecz, Festuca ovina L., Poa annua L., V Potentilla discolor Bge and Potentilla fulgens Wall. ex Hook.

\section{Experiment Design}

Fertilization in prairie: Choose $180 \mathrm{~kg}$ nitrogen per hectare grassland as the amount of experiment nitrogen fertilizer. We calculated the weight of fertilizer by electronic balance and fertilized by artificial sowing. The experiment was divided into 3 treatments. Treatment 1: ammonium sulfate $\left[\left(\mathrm{NH}_{4}\right)_{2} \mathrm{SO}_{4}\right]$ 
fertilization. Treatment 2: ammonium nitrate $\left(\mathrm{NH}_{4} \mathrm{NO}_{3}\right)$ fertilization. Treatment 3: control group, no fertilization. The experiment began July 1, 2017 and ended October 1, 2017. Selection of grazing animals: we chose 18 rams of one-year-old sheep (20 kg weight with similar development and nutrition status, health testified by clinical examination), randomly divided them into 3 groups with 6 in each group and then randomly assigned them to the experimental prairie.

\section{Sample Collection}

Before the start of the experiment, soil samples were collected in the fertilization and control prairies. Respectively we collected 10 samples in treatment 1 , treatment 2 and treatment 3, with a depth of $1-20 \mathrm{~cm}$. The soil samples were bagged after removing debris such as stones and residual roots. At the start and end of the experiment we respectively collected 10 mixed grass samples that were collected in treatment 1 , treatment 2 and treatment 3, and collected jugular blood from 18 test animals $(15 \mathrm{ml}$ per animal).

\section{Sample Preparation}

Forage samples were naturally air-dried at 20$25^{\circ} \mathrm{C}$, crushed, and then sieved through $0.175 \mathrm{~mm}$ sieve and bagged for use. Before the test, the wall of the digestive tract was rinsed with a small amount of deionized water. Then we took approximately $0.5 \mathrm{~g}$ soil samples into the digestive tract, added $6 \mathrm{ml}$ nitric acid $\left(\mathrm{HNO}_{3}\right)$ and $1 \mathrm{ml}$ hydrogen peroxide $\left(\mathrm{H}_{2} \mathrm{O}_{2}\right)$, shook well, and let it statically set for $10 \mathrm{~min}$. The samples were based on microwave digestion procedure, cooled, and transferred into $100 \mathrm{ml}$ volumetric flasks and diluted to scale [6].

Blood samples were anticoagulated with heparin sodium. After the blood became cold, it was transported back to the laboratory at a low temperature $\left(4-8^{\circ} \mathrm{C}\right)$ in $4 \mathrm{~h}$ for the analysis of mineral elements, blood routine, physiological and biochemical indexes and antioxidant indexes.

\section{Analysis of Mineral Contents}

The content of mineral elements in soil, forage and blood was determined by inductively coupled plasma atomic emission spectroscopy (ICP-AES) [5]. The determination instrument is an inductively coupled plasma emission spectrometer (HK9600 Type Atomic Emission Spectroscope, Huaketiancheng Co., Ltd, China). At the start of the determination, we turned on the inductively coupled plasma emission spectrometer based on its operation program and entered the operating software of the Winlab32 system. After the plasma was ignited, the blank solution, the standard solution and the sample solution were sequentially tested.

\author{
Physiological and Biochemical \\ Examination
}

White blood cell count (WBC), red blood cell count (RBC), hemoglobin concentration (HGB), hematocrit (HCT), mean corpuscular volume (MCV), mean corpuscular hemoglobin $(\mathrm{MCH})$ and mean corpuscular hemoglobin concentration (MCHC) in whole blood were detected by automatic blood cell analyzer (SF-3000, Sysmex-Toa Medical Electronics, Kobe, Japan). The activity and content of alanine aminotransferase (ALT), alkaline phosphatase (AKP), lactate dehydrogenase (LDH), aspartate aminotransferase (AST), glutamyl transpeptidase $(\gamma-\mathrm{GT})$, blood urea nitrogen (BUN), total cholesterol (Chol), ceruloplasmin (Cp), superoxide dismutase (SOD), glutathione peroxidase (GSH-Px), catalase (CAT) and malondialdehyde (MDA) in blood plasma were detected by automatic biochemical analyzer (OLYMPUS AU 640, Olympus Optical Co., Tokyo, Japan). Quality control serum (Shanghai Biochemical Co., Shanghai, China) was used to validate blood biochemistry data).

\section{Statistical Analysis}

The study data was analyzed by SPSS20.0 for Windows statistical software. After the test, we found that the data distribution was normal distribution. The difference of mineral elements in forage in different varieties and different periods was analyzed by one-way ANOVA. Data are expressed as mean $(\bar{x}) \pm$ standard deviation (S).

\section{Results and Analysis}

\section{Effects of Fertilization on Nutritive Value in Forage}

Fertilization markedly increased nitrogen content of forage $(\mathrm{P}<0.01)$, but there was no significant difference between different fertilization treatments. The content of sulfur in forage enriched with ammonium sulfate was significantly higher than that enriched with ammonium nitrate fertilization and control group $(\mathrm{P}<0.01)$, but there was no significant difference between the forage enriched with ammonium nitrate fertilization and control group (Table 1).

\section{Effects of Fertilization on Mineral Contents in Forage}

The content of selenium in forage enriched with ammonium sulfate was significantly lower than that enriched with ammonium nitrate and control prairie $(\mathrm{P}<0.01)$, but there was no significant difference in selenium content of forage between ammonium nitrate fertilization prairie and control prairie. Fertilization of ammonium sulfate and ammonium nitrate had no 
Table 1. Effects of fertilization on mineral nutrition in forage (\%).

\begin{tabular}{|c|c|c|c|c|c|c|}
\hline \multirow{2}{*}{ Items } & \multicolumn{2}{|c|}{ Ammonium sulfate } & \multicolumn{2}{c|}{ Ammonium nitrate } & \multicolumn{2}{c|}{ Control } \\
\cline { 2 - 7 } & Start & End & Start & End & Start & End \\
\hline IVOMD & $45.16 \pm 5.33$ & $45.87 \pm 6.37$ & $46.15 \pm 6.87$ & $47.93 \pm 7.37$ & $47.79 \pm 6.77$ & $47.98 \pm 7.32$ \\
\hline$S$ & $0.32 \pm 0.01^{\mathrm{a}}$ & $0.47 \pm 0.01^{\mathrm{b}}$ & $0.32 \pm 0.01^{\mathrm{a}}$ & $0.32 \pm 0.01^{\mathrm{a}}$ & $0.31 \pm 0.01^{\mathrm{a}}$ & $0.32 \pm 0.01^{\mathrm{a}}$ \\
\hline $\mathrm{N}$ & $1.31 \pm 0.18^{\mathrm{a}}$ & $2.59 \pm 0.22^{\mathrm{b}}$ & $1.33 \pm 0.12^{\mathrm{a}}$ & $2.47 \pm 0.15^{\mathrm{b}}$ & $1.46 \pm 0.13^{\mathrm{a}}$ & $1.49 \pm 0.12^{\mathrm{a}}$ \\
\hline
\end{tabular}

Note: with different superscripts within a line indicate significant differences at 0.01 levels.

IVOMD: In Vitro Organic Matter Digestibility

Table 2. Effects of fertilization on mineral contents in forage $(\mu \mathrm{g} / \mathrm{g})$.

\begin{tabular}{|c|c|c|c|c|c|c|}
\hline \multirow{2}{*}{ Element } & \multicolumn{2}{|c|}{ Ammonium sulfate } & \multicolumn{2}{c|}{ Ammonium nitrate } & \multicolumn{3}{c|}{ Control } \\
\cline { 2 - 7 } & Start & End & Start & End & Start & End \\
\hline $\mathrm{Mn}$ & $61.78 \pm 5.71$ & $62.96 \pm 7.37$ & $64.26 \pm 7.53$ & $63.97 \pm 6.76$ & $67.77 \pm 8.56$ & $68.87 \pm 5.69$ \\
\hline $\mathrm{Cu}$ & $4.67 \pm 1.25$ & $4.59 \pm 1.27$ & $4.57 \pm 1.21$ & $4.59 \pm 1.13$ & $4.63 \pm 1.13$ & $4.57 \pm 1.27$ \\
\hline $\mathrm{Fe}$ & $627.87 \pm 9.67$ & $619.86 \pm 8.66$ & $625.65 \pm 9.89$ & $627.35 \pm 9.67$ & $619.35 \pm 9.87$ & $622.35 \pm 8.76$ \\
\hline $\mathrm{Mo}$ & $0.73 \pm 0.12$ & $0.75 \pm 0.13$ & $0.82 \pm 0.11$ & $0.81 \pm 0.12$ & $0.83 \pm 0.13$ & $0.82 \pm 0.12$ \\
\hline $\mathrm{Se}$ & $0.06 \pm 0.02^{\mathrm{a}}$ & $0.03 \pm 0.01^{\mathrm{b}}$ & $0.06 \pm 0.01^{\mathrm{a}}$ & $0.07 \pm 0.01^{\mathrm{a}}$ & $0.06 \pm 0.01^{\mathrm{a}}$ & $0.07 \pm 0.01^{\mathrm{a}}$ \\
\hline
\end{tabular}

Note: with different superscripts within a line indicate significant differences at 0.01 levels.

significant effect on the content of other trace elements in forage (Table 2).

\section{Effects of Fertilization Treatment on Mineral Content in Blood}

At the beginning of the experiment, the content of mineral elements in blood of the Wumeng semi-fine sheep did not differ significantly among each treatment. At the end of the experiment, contents of zinc and sulfur in the blood of sheep in the prairie enriched with ammonium sulfate was significantly higher than that in the prairie enriched with ammonium nitrate and control prairie $(\mathrm{P}<0.01)$. But contents of zinc and sulfur in the blood of the sheep in the prairie enriched with ammonium nitrate had no significant difference from that in the control prairie. Contents of copper, iron and selenium in the blood of the sheep on the grassland enriched with ammonium sulfate was significantly lower from that in the grassland enriched with ammonium nitrate and the control group $(\mathrm{P}<0.01)$. But content of copper, iron and selenium in the blood of the Wumeng semi-fine wool sheep on the prairie enriched with ammonium nitrate has no significant difference with that on the control group. Fertilization of ammonium sulfate and ammonium nitrate had no significant effect on the contents of other blood parameters (Table 3).

\section{Effects of Fertilization on Physiological Parameters in Blood}

At the beginning of the experiment, the blood parameters of the sheep did not differ significantly among treatments. At the end of the experiment, the

Table 3. Effect of fertilization on the content of trace elements in the blood of Wumeng semi-fine sheep $(\mu \mathrm{g} / \mathrm{g})$.

\begin{tabular}{|c|c|c|c|c|c|c|}
\hline \multirow{2}{*}{ Element } & \multicolumn{2}{|c|}{ Ammonium sulfate } & \multicolumn{2}{c|}{ Ammonium nitrate } & \multicolumn{2}{c|}{ Control } \\
\cline { 2 - 7 } & Start & End & Start & End & Start & End \\
\hline $\mathrm{Mn}$ & $0.26 \pm 0.03$ & $0.25 \pm 0.02$ & $0.27 \pm 0.03$ & $0.26 \pm 0.02$ & $0.24 \pm 0.02$ & $0.23 \pm 0.01$ \\
\hline $\mathrm{Cu}$ & $0.48 \pm 0.07^{\mathrm{a}}$ & $0.24 \pm 0.03^{\mathrm{b}}$ & $0.47 \pm 0.06^{\mathrm{a}}$ & $0.48 \pm 0.05^{\mathrm{a}}$ & $0.45 \pm 0.07^{\mathrm{a}}$ & $0.46 \pm 0.06^{\mathrm{a}}$ \\
\hline $\mathrm{Fe}$ & $456.89 \pm 22.17^{\mathrm{a}}$ & $327.68 \pm 23.98^{\mathrm{b}}$ & $422.67 \pm 21.35^{\mathrm{a}}$ & $425.76 \pm 28.26^{\mathrm{a}}$ & $429.77 \pm 21.15^{\mathrm{a}}$ & $423.73 \pm 27.54^{\mathrm{a}}$ \\
\hline $\mathrm{Mo}$ & $0.33 \pm 0.02$ & $0.35 \pm 0.02$ & $0.36 \pm 0.03$ & $0.34 \pm 0.03$ & $0.36 \pm 0.02$ & $0.34 \pm 0.03$ \\
\hline $\mathrm{Se}$ & $0.09 \pm 0.02^{\mathrm{a}}$ & $0.05 \pm 0.01^{\mathrm{b}}$ & $0.09 \pm 0.02^{\mathrm{a}}$ & $0.08 \pm 0.01^{\mathrm{a}}$ & $0.09 \pm 0.03^{\mathrm{a}}$ & $0.08 \pm 0.02^{\mathrm{a}}$ \\
\hline
\end{tabular}

Note: with different superscripts within a line indicate significant differences at 0.01 levels. 
Table 4. Effects of fertilization on blood routine parameters in Wumeng semi-fine sheep.

\begin{tabular}{|c|c|c|c|c|c|c|}
\hline \multirow{2}{*}{$\begin{array}{c}\text { Blood } \\
\text { parameters }\end{array}$} & \multicolumn{2}{|c|}{ Ammonium sulfate } & \multicolumn{2}{c|}{ Ammonium nitrate } & \multicolumn{2}{c|}{ Control } \\
\cline { 2 - 7 } & Start & End & Start & End & Start & End \\
\hline $\mathrm{Hb}(\mathrm{g} / \mathrm{L})$ & $125.67 \pm 17.35^{\mathrm{a}}$ & $73.58 \pm 15.46^{\mathrm{b}}$ & $121.39 \pm 11.67^{\mathrm{a}}$ & $126.87 \pm 15.36^{\mathrm{a}}$ & $124.77 \pm 15.39^{\mathrm{a}}$ & $125.68 \pm 16.77^{\mathrm{a}}$ \\
\hline $\mathrm{RBC}\left(10^{12} / \mathrm{L}\right)$ & $9.37 \pm 1.58$ & $9.29 \pm 1.17$ & $9.57 \pm 1.78$ & $9.76 \pm 1.81$ & $9.65 \pm 1.17$ & $9.56 \pm 1.68$ \\
\hline $\mathrm{PCV}(\%)$ & $38.72 \pm 2.93^{\mathrm{a}}$ & $29.56 \pm 2.75^{\mathrm{b}}$ & $37.76 \pm 2.27^{\mathrm{a}}$ & $37.89 \pm 2.48^{\mathrm{a}}$ & $36.85 \pm 2.27^{\mathrm{a}}$ & $37.39 \pm 2.78^{\mathrm{a}}$ \\
\hline $\mathrm{WBC}\left(10^{9} / \mathrm{L}\right)$ & $9.57 \pm 1.18$ & $9.69 \pm 1.53$ & $9.38 \pm 1.37$ & $9.39 \pm 1.78$ & $9.38 \pm 1.29$ & $9.29 \pm 1.31$ \\
\hline
\end{tabular}

Note: with different superscripts within a line indicate significant differences at 0.01 levels.

content of hemoglobin $(\mathrm{Hb})$ and packed cell volume (PCV) of the Wumeng semi-fine sheep in prairie enriched with ammonium sulfate was significantly lower than that in prairie enriched with ammonium nitrate and control group $(\mathrm{P}<0.01)$. But the content of $\mathrm{Hb}$ and $\mathrm{PCV}$ of the sheep in prairie enriched with ammonium nitrate had no significant difference with control group. Ammonium sulfate and ammonium nitrate fertilization had no significant effect on blood red blood cell count (RBC) and white blood cell count (WBC) of the sheep (Table 4).

\section{Effects of Fertilization on Biochemical Parameters in Serum}

There was no significant difference in serum antioxidant enzymes at the start of the experiment. At the end of the experiment, serum ceruloplasmin, superoxide dismutase, glutathione peroxidase and catalase of the sheep in the prairie enriched with ammonium sulfate were significantly lower than that in prairie enriched with ammonium nitrate and control group $(\mathrm{P}<0.01)$. But these parameters had no significant difference between ammonium nitrate fertilization prairie and control group. Ammonium sulphate and ammonium nitrate fertilization had no significant effect on lactate dehydrogenase, alkaline phosphatase, aspartate aminotransferase, alanine aminotransferase, glutamic-pyruvic transaminase, blood urea nitrogen and total cholesterol of the sheep (Table 5).

\section{Discussion}

Mineral elements are one of the main nutrients for plants and animals [5], but its absorption and utilization are affected by many factors. Previous studies have shown that ammonium sulphate fertilization significantly increases the sulphur content of the forage without increasing the forage yield. A study in the Shouqu Alpine Meadow of the Yellow River was carried out for three consecutive years, the results of which showed that the sulphur content in the forage was $0.23 \%$ with $86 \mathrm{~kg} / \mathrm{ha}$ ammonium sulphate for fertilization, $3.0 \%$ with $174 \mathrm{~kg} / \mathrm{ha}$ ammonium sulphate for fertilization and $0.1 \%$ when there was no sulphur fertilizer [4].

Table 5. Effects of fertilization on biochemical parameters in blood of Wumeng semi-fine sheep.

\begin{tabular}{|c|c|c|c|c|c|c|}
\hline \multirow{2}{*}{ Values } & \multicolumn{2}{|c|}{ Ammonium sulfate } & \multicolumn{2}{c|}{ Ammonium nitrate } & \multicolumn{2}{c|}{ Control } \\
\cline { 2 - 7 } & Start & End & Start & End & Start & End \\
\hline AKP(IU/L) & $269.54 \pm 11.33$ & $271.65 \pm 12.78$ & $273.55 \pm 17.68$ & $277.46 \pm 11.53$ & $279.65 \pm 11.37$ & $278.56 \pm 13.36$ \\
\hline AST(IU/L) & $36.28 \pm 8.51$ & $35.76 \pm 8.12$ & $36.39 \pm 7.16$ & $36.27 \pm 8.52$ & $35.56 \pm 8.73$ & $36.75 \pm 8.97$ \\
\hline ALT(IU/L) & $11.87 \pm 2.34$ & $11.76 \pm 2.17$ & $11.85 \pm 2.36$ & $11.69 \pm 2.45$ & $11.65 \pm 2.38$ & $11.63 \pm 2.17$ \\
\hline$\gamma-G T(I U / L)$ & $16.79 \pm 2.59$ & $16.58 \pm 2.11$ & $16.19 \pm 2.31$ & $17.71 \pm 2.37$ & $17.32 \pm 2.27$ & $17.51 \pm 2.49$ \\
\hline BUN $(\mathrm{mmol} / \mathrm{L})$ & $5.97 \pm 1.52$ & $5.98 \pm 1.49$ & $6.11 \pm 1.35$ & $6.12 \pm 1.23$ & $6.14 \pm 1.31$ & $6.13 \pm 1.21$ \\
\hline Chol $(\mathrm{mmol} / \mathrm{L})$ & $2.57 \pm 0.23$ & $2.53 \pm 0.21$ & $2.58 \pm 0.21$ & $2.53 \pm 0.23$ & $2.52 \pm 0.15$ & $2.53 \pm 0.27$ \\
\hline $\mathrm{Cp}(\mathrm{mg} / \mathrm{L})$ & $53.77 \pm 3.16 \mathrm{a}$ & $37.56 \pm 3.56 \mathrm{~b}$ & $53.79 \pm 3.27 \mathrm{a}$ & $51.97 \pm 3.27 \mathrm{a}$ & $52.73 \pm 3.95 \mathrm{a}$ & $52.76 \pm 3.17 \mathrm{a}$ \\
\hline $\mathrm{SOD}\left(\mu \mathrm{mol} . \mathrm{s}^{-1} / \mathrm{L}\right)$ & $17.35 \pm 1.57 \mathrm{a}$ & $11.89 \pm 1.78 \mathrm{~b}$ & $16.97 \pm 1.69 \mathrm{a}$ & $16.86 \pm 1.37 \mathrm{a}$ & $17.17 \pm 1.19 \mathrm{a}$ & $16.68 \pm 1.43 \mathrm{a}$ \\
\hline $\mathrm{GSH}-\mathrm{PX}\left(\mu \mathrm{mol} . \mathrm{s}^{-1} / \mathrm{L}\right)$ & $19.65 \pm 1.37 \mathrm{a}$ & $12.17 \pm 1.32 \mathrm{~b}$ & $18.97 \pm 1.61 \mathrm{a}$ & $18.89 \pm 1.56 \mathrm{a}$ & $19.73 \pm 1.31 \mathrm{a}$ & $19.69 \pm 1.23 \mathrm{a}$ \\
\hline $\mathrm{CAT}(\mathrm{U} / \mathrm{mL})$ & $1.97 \pm 0.15 \mathrm{a}$ & $1.23 \pm 0.13 \mathrm{~b}$ & $1.87 \pm 0.12 \mathrm{a}$ & $1.89 \pm 0.12 \mathrm{a}$ & $1.87 \pm 0.15 \mathrm{a}$ & $1.88 \pm 0.13 \mathrm{a}$ \\
\hline $\mathrm{MDA}(\mathrm{nmol} / \mathrm{L})$ & $14.73 \pm 1.51 \mathrm{a}$ & $19.77 \pm 1.43 \mathrm{~b}$ & $16.37 \pm 1.41 \mathrm{a}$ & $16.16 \pm 1.35 \mathrm{a}$ & $16.68 \pm 1.10 \mathrm{a}$ & $16.78 \pm 1.46 \mathrm{a}$ \\
\hline
\end{tabular}

Note: with different superscripts within a line indicate significant differences at 0.01 levels. 
In the current study, fertilization with ammonium sulfate containing $180 \mathrm{~kg}$ nitrogen significantly increased the sulfur content of the forage [6, 7]. Simultaneously, studies have shown that sulphur can interfere with the absorption of copper and then cause the lack of copper in Wumeng sheep. Copper is an essential element for the catalytic activity of superoxide dismutase. Superoxide dismutase cannot maintain its activity when any other element replaces copper ions. Therefore, the lack of copper in animals will seriously affect the activity of superoxide dismutase $[5,6]$.

The effect of copper deficiency on catalase is affected by the effect of blood iron levels. The lack of copper in animals and the decrease in liver copper storage eventually lead to the decrease of copper concentration and ceruloplasmin concentration in blood. Whereas ceruloplasmin can carry $\mathrm{Fe}^{3+}$ out of the cell through the cell membrane, the reduced concentration of ceruloplasmin causes the iron stored in the tissue not to be mobilized. Then iron will be retained in phagocytic cells, iron stored in cells cannot enter the bloodstream, and iron accumulates inside the cell membrane, causing a decrease in blood iron content [7-9]. Catalase is a heme enzyme. Although the structure of catalase from different sources is different, most of them are composed of four identical subunits, each of which has more than one active part centered with a high degree of spin $\mathrm{Fe}^{3+}$ [10-12]. When the iron content is reduced, it will inevitably cause a decrease in catalase activity, which will damage the organism's antioxidant system function. Catalase is one of the key enzymes in the biological defense system established by organisms in the process of evolution. It is ubiquitous in almost all respiratory organisms and plays an important role in the membrane system that scavenges hydrogen peroxide and protects cells [13-15].

Sulfur is an important factor affecting the absorption of selenium by plants. The solubility of selenate in soil is greater than that of selenite, which often coexists with sulphate and is easily absorbed by plants [16-18]. There is an antagonistic effect between sulphate and selenate. At the root of the plant, selenate competes with sulphate for the same absorption site, that is, selenate and sulphate are bound to the same carrier on cell walls at the root of the plant with the same affinity, so that the concentration ratio of the two substances determines the extent to which they are absorbed $[19,20]$. Consequently, the interaction between sulfur and selenium is the main reason for the decrease of selenium content in forage with ammonium sulfate fertilization. Selenium is one of the essential mineral elements in humans and animals. It is the active central element of glutathione peroxidase. Glutathione peroxidase can remove peroxide and hydrogen peroxide from the organism [21-23]. Selenium plays an antioxidant role mainly through glutathione peroxidase, and selenium deficiency causes a decrease in glutathione peroxidase activity, which seriously affects the organism's antioxidant system function [24-27].

\section{Conclusions}

In summary, applying ammonium sulfate fertilizer in low copper forage can increase sulfur content and decrease selenium content in forage, causing selenium and copper deficiency in animals through the food chain due to the interaction of copper and sulfur in the ecosystem. Therefore, it is not suggested to use sulfur-containing fertilizers in prairies with relatively low copper and selenium contents. Applying sulfur-containing fertilizers in low-copper prairies will result in the deficiency of secondary copper in ruminants of grazing animals because of the increase of sulphur content in plants. Applying sulfur-containing fertilizers in prairies with low selenium content will reduce the selenium content of forage, lead to the selenium deficiency of animals, affect the growth and development of animals, cause various diseases of animals and, ultimately, adversely affect the whole ecosystem through material circulation and energy flow.

\section{Acknowledgements}

We gratefully acknowledge support by the Project of National Key Research and Development Program of China in the 13th Five-year Plan (2016YFC0502601), the Program of National Natural Science Foundation of China (No. 41671041), the Southwest University of Science and Technology Doctoral Research Fund (No.17zx7146), the Key Project of Science and Technology Program of Guizhou Province (Qian Ke He Zhong Da Zhuan Xiang Zi [2014] 6007), the Project of Science and Technology Program of Guizhou Province (Qian Ke He She G Zi [2012] 4008), the Project of Innovation Program for Postgraduate Education of Guizhou Province (QIANJIAOYANHE GZS ZI [2016]04), and the Project of National Key Innovation Base Construction (GUOKEFAJI [2013] 405, 2012FU125X13).

\section{Conflict of Interest}

The authors declare no conflict of interest.

\section{References}

1. SHEN X.Y., CHI Y.K., XIONG, K.N., CHENG W.H., ZHANG J.H. Serum biochemical values and mineral contents of tissues in Guizhou semi-fine wool sheep. Journal of animals and veterinary advance, 12 (11), 1078, 2013.

2. CHI Y.K., XIONG, K.N., CHEN H., MIN X.Y., XIAO H., LIAO J.J., SHEN X.Y. Effect of nitrogenous fertilizer on the antioxidant systems of grassland species in the karst mountains. Polish Journal of Environmental Studies, 27 (3), 2019. DOI: $10.15244 /$ pjoes $/ 87102$ 
3. SHEN X.Y., JIANG H.M., YUAN R., ZHANG J.H. Effect of grazing to copper pollution meadow on copper metabolism in Wumeng semi-fine wool sheep. Acta Prataculturae Sinica, 21 (3), 275, 2012.

4. SHEN X.Y. Effect of nitrogenous fertilizer treatment on mineral metabolism in grazing yaks. Journal of Integrative Agriculture, 8 (3), 361, 2009.

5. SHEN X.Y., DU G.Z., LI H. Studies of a naturally occurring molybdenum-induced copper deficiency in the yak. The Veterinary Journal, 171 (2), 352, 2006.

6. ARTHINGTON J.D., RECHCIGL J.E., YOST G.P., MCDOWELL R., FANNING M.D. Effect of ammonium sulfate fertilization on bahiagrass quality and copper metabolism in grazing beef cattle. Journal of Animal Science, 80 (10), 2507, 2002.

7. SHEN X.Y., CHI Y.K., HUO B., WU T., XIONG K.N. Effect of fertilization on ryegrass quality and mineral metabolism in grazing the Wumeng semi-fine wool sheep. Fresenius Environmental Bulletin, 26 (10), 6824, 2018.

8. CHAN Y.H., SIU C.W., YIU K.H. Adverse systemic arterial function in patients with selenium deficiency. Journal of Nutrition Health and Aging, 16 (1), 85, 2012.

9. HURST R., SIYAME E.W., YOUNG S.D., CHILIMBA A.D.C., JOY E.J.M., BLACK C.R. Soil-type influences human selenium status and underlies widespread selenium deficiency risks in Malawi. Scientific reports, 3 (2), 1425, 2013.

10. LIU C.P., FU J., LIN S.L., WANG X.S., LI S. Effects of dietary selenium deficiency on mRNA levels of twenty-one selenoprotein genes in the liver of layer chicken. Biological trace element research, 159 (3), 192, 2014.

11. NANGLIYA V., SHARMA A., YADAV D., SUNDER S., NIJHAWAN S., MISHRA S. Study of trace elements in liver cirrhosis patients and their role in prognosis of disease. Biological Trace Element Research, 160 (1), 135, 2015.

12. XU S.W., YAO H.D., ZHANG J. The oxidative damage and misbalance of calcium homeostasis in brain of chicken induced by selenium deficiency. Biological Trace Element Research, 151 (2), 225, 2013.

13. LONGKUMER L.T., SINGH A.K., JAMIR Z., KUMAR M.. Effect of sulfur and boron nutrition on yield and quality of soybean (glycine max L.) grown in an acid soil. Communications in Soil Science \& Plant Analysis, 48 (4), 405, 2017.

14. SHEN X.Y., LI X., ZHANG R.D. Studies of "Unsteady Gait Disease" of the Tibetan Gazelle (Procapra picticaudata). Journal of Wildlife Diseases, 46 (2), 560, 2010.

15. WRIGHTON K.C. Fermentation, hydrogen, and sulfur metabolism in multiple uncultivated bacterial phyla. Science, 338 (6102), 1661, 2012.
16. AMAT S., OLKOWSKI A.A., ATILA M., O’NEILL T. A review of polioencephalomalacia in ruminants: is the development of malacic lesions associated with excess sulfur intake independent of thiamine deficiency? Veterinary Medicine \& Animal Sciences, 1 (1), 1, 2013.

17. RZEŹNIK W., MIELCAREK P. Greenhouse Gases and Ammonia Emission Factors from Livestock Buildings for Pigs and Dairy Cows. Polish Journal of Environmental Studies, 25 (5), 1831, 2016.

18. XIONG K.N., CHI Y.K., SHEN, X.Y. Research on photosynthetic leguminous forage in the karst rocky desertification regions of southwestern china. Polish Journal of Environmental Studies, 26 (5), 2319, 2017.

19. RADWIŃSKA J., ŻARCZYŃSKA K. Effects of mineral deficiency on the health of young ruminants. Journal of Elementology, 19 (3), 915, 2014.

20. PONTESA L.D.S., BARROB R.S., SAVIANB J.V., BERNDTC A., MOLETTAA J.L., PORFIRIO V. Performance and methane emissions by beef heifer grazing in temperate pastures and in integrated crop-livestock systems: the effect of shade and nitrogen fertilization. Agriculture Ecosystems \& Environment, 253, 90, 2017.

21. ARTHINGTON J.D., JAYNES C.A., TYLER H.D., KAPIL S. The use of bovine serum protein as an oral support therapy following coronavirus challenge in calves. Journal of Dairy Science, 85 (5), 1249, 2002.

22. GORAN K. Nutrient requirements of sheep and goats. Zbornik Predavanja.savjetovanje Uzgajivač, 10, 11, 2017.

23. AZAD S.K., SHARIATMADARI F., TORSHIZI M.A.K., AHMADI H. (2017). Effect of zinc concentration and source on performance, tissue mineral status, activity of superoxide dismutase enzyme and lipid peroxidation of meat in broiler chickens. Animal Production Science, https://doi.org/10.1071/AN15758, 2017.

24. LI X.M., CHEN T.F., PENG A.Q., LUO Y., ZHANG X.Q., YAN Y.H. Effects of different nitrogen fertilizer forms on production and quality of italian ryegrass. Acta Agrestia Sinica, 25 (6), 1368, 2017.

25. CASTAGNARA D.D., NERES M.A., OLIVEIRA P.S.R.D., MEINERZ C.C., MESQUITA E.E. Use of conditioning in the production of black and white oat hay using two cutting heights. Revista Brasileira De Zootecnia, 41 5), 1082, 2012.

26. ANDREOLLA V.R.M., MORAES A.D., BONA A., SANDINI I.E., BONINI A.K., DEISS L. Grazing and nitrogen on ryegrass over soil physical properties and bean yield. Eng Agríc, 35 (1), 11, 2015.

27. JOINES D.K., SAVOY H.J. Evaluation of Sulfur Fertilization Effects on Yield, Quality, and Nutrient Content of Bermudagrass Hay. Communications in Soil Science \& Plant Analysis, 45 (7), 9343, 2014. 
